\title{
Survey Studies on Seasonal Abundance of Parasitoids associated with Cnaphalocrocis medinalis Guenee in Zone I and Zone II of Himachal Pradesh, India
}

\author{
Chhavi*, Pawan K. Sharma and P. C. Sharma
}

Department of Entomology, CSK Himachal Pradesh Krishi Vishvavidyalaya, Palampur-176062, India

*Corresponding author

\section{A B S T R A C T}

Keywords

Cnaphalocrocis medinalis,

parasitoids, rice,

Cotesia

Article Info

Accepted:

25 November 2019

Available Online:

10 December 2019
Seasonal abundance studies on parasitoids associated with rice leaf folder, Cnaphalocrocis medinalis were carried out during 2015 and 2016 in two agro-ecological zones of Himachal Pradesh i.e. Zone I (Sundernagar and Nurpur) and Zone II (Palampur and Jogindernagar). Five parasitoids namely, Cotesia cypris Nixon, C. ruficrus Haliday, Trathala flavoorbitalis Cameron, Elasmus sp., and tachnid fly were recorded to be specific to rice leaf folder larvae. Parasitization of rice leaf folder larvae by $C$. cypris varied from 7.14 to 44.45 per cent which was found to be the higher in all the four locations followed by tachnid fly (4.55-15.38\%).

\section{Introduction}

Rice (Oryza sativa L.) is cultivated extensively in the most diverse ecosystems of tropical and subtropical regions of the world (Karthick et al., 2014). Rice crop has a relatively large number of insect-pests associated with it which attack the rice crop from nursery stage till harvest. Of hundred insect-pests attacking rice nearly 20 species had been reported as major pests (Basit and Bhattacharya 2001). The yield loss due to insect-pests of rice ranges from 25 to 51 per cent (Panda and Rath, 2003). Among various pests of rice, Cnaphalocrocis medinalis has been observed to be major and serious pest due to over use of insecticides, monocropping, introduction of high yielding varieties and adoption of new agronomic practices (Litsinger et al., 1987). The yield losses due to this pest were reported to be about 11.2 per cent in India (Shanmugam et al., 2006).

Several natural enemies (predators, parasitoids and pathogens) under field conditions play a dominant role in maintaining several species 
of insect-pests of rice below economic threshold level. A diverse complex of natural enemies has been found associated with rice leaf folder, which includes over 200 different species of parasitoids, predators and pathogens all over Asia and Pacific (Khan et al., 1988). Among parasitoids, Trichogramma chilonis (Ishii) and Apanteles cypris (Nixon) were most abundant in rice fields. In Gujarat, Korat and Pathak (1996) reported egg parasitoids ( $T$. chilonis), larval parasitoid (Apanteles sp. and Goniozus sp.) and pupal parasitoids (Tetrastichus howardi Olliff and Anatrichus sp.) associated with rice leaf folder. Hence, these natural biological control agents are responsible for managing the population of rice insect-pests whenever suitable conditions prevail for the survival, development, conservation and multiplication (Bhattacharya et al., 2006).

In Kangra valley of Himachal Pradesh, Kumar et al., (1997) observed seven species of parasitoids and five of predators prevalent in rice ecosystem. The information currently available on natural enemies associated with rice leaf folder from Kangra valley of Himachal Pradesh is still scanty. Keeping in view the above facts, an attempt was made to document the potential parasitoids associated with leaf folder larvae and their parasitism rates from Himachal Pradesh.

\section{Materials and Methods}

Survey on the prevalence of parasitoids associated with rice leaf folder larvae was made at fortnightly interval in two agroecological zones of Himachal Pradesh i.e. Zone I and II. Two locations in each agroecological zone and four different localities in each location were selected for recording the abundance of parasitoids associated with rice leaf folder larvae starting from June to November during kharif 2015 and 2016. Details of locations and localities surveyed for recording abundance of parasitoids are given in Table 1.

On an average, 100 folded leaves were collected at 15 days intervals from all the four locations and from these folded leaves, larvae of leaf folder were collected. Larvae were reared individually in collection vials. To maintain the turgidity of leaf bits, moistened cotton wool covered with filter paper was used. The leaf bits were changed every 24 hours till the larvae pupated. The larvae and pupae were observed for the emergence of parasitoids.

The per cent parasitization was calculated as below:

$\%$ parasitization

Number of parasitized larvae

$=\longrightarrow \times 100$

Total number of leaf

folder larvae

\section{Results and Discussion}

Seasonal abundance of parasitoids associated with Cnaphalocrocis medinalis

Rearing of field collected larvae of rice leaf folder resulted in emergence of larval parasitoids and the data on per cent parasitization by parasitoids is being presented in Table 2 to 7.

\section{Sundernagar}

The data recorded on number of parasitized larvae from total number of leaf folder larvae during 2015 presented in Table 2 revealed that five species of parasitoids namely, Cotesia cypris, C. ruficrus, Elasmus sp., Trathala flavorbitalis and tachnid fly were found to be associated with leaf folder (Fig. 1). The parasitization initiated from first fortnight of August and remained until second fortnight of 
October. Total number of leaf folder larvae from 100 damaged leaves varied from 2.00 to 22.00 and the number of parasitized larvae ranged between 1.00 to 10.00 . During second fortnight of September, the per cent parasitization $(31.25 \%)$ was maximum by $C$. cypris followed by tachnid fly, C. ruficrus, Elasmus sp., and T. flavoorbitalis with 12.50, $6.25,6.25$ and 6.25 per cent parasitization, respectively, and the total parasitization was 62.50 per cent.

During 2016, the total number of larvae from damaged leaves varied from 1.00 to 18.00 (Table 3). The parasitization was first observed in second fortnight of August with 20 per cent parsitization and it kept on increasing and reached peak during second fortnight of September $(60.00 \%)$. The per cent parasitization was maximum by $C$. cypris (26.66\%) followed by tachnid fly (13.33\%), C. ruficrus (6.67\%), Elasmus sp. (6.67\%) and $T$. flavoorbitalis $(6.67 \%)$ during second fortnight of September.

\section{Nurpur}

Data contained in Table 4 revealed that $C$. cypris was the only larval parasitoid associated with leaf folder larvae at Nurpur location which resulted in parasitization varying from 10.00 to 14.29 and 8.33 to 20.00 per cent during 2015 and 2016, respectively.

It was observed that parasitization by $C$. cypris initiated in first fortnight of September and reached the peak of 14.25 and 20.00 during 2015 and 2016, respectively in first fortnight of October.

\section{Jogindernagar}

Observations recorded on parasitization by $C$. cypris at Jogindernagar presented in Table 5 revealed that the activity of parasitoids initiated in first fortnight of September with
7.14 per cent parasitization during 2015 and reached the peak of 20.00 per cent in the first fortnight of October. During 2016, parasitization initiated in second fortnight of August (12.50\%) and was maximum (22.22\%) in first fortnight of October when the larval population and parasitized larvae were 9.00 and 2.00 , respectively.

\section{Palampur}

Data presented in Table 6 and 7 revealed that at Palampur, five parasitoids were found associated with leaf folder larvae. Among them, $C$. cypris was found to be the most dominating followed by tachnid fly, $C$. ruficrus, Elasmus sp. and T. flavoorbitalis during both the study years (Fig. 1). A perusal of data presented in Table 6 revealed that during 2015 activity of leaf folder larvae started during second fortnight of August with 14.29 per cent parasitization and remained associated till the final harvest of the crop. The parasitization reached the peak (64.29\%) in the first fortnight of October. It was also observed that when number of parasitized larvae were maximum, parasitoids, namely, $C$. cypris, C. ruficrus, Elasmus sp., $\quad T$. flavoorbitalis and tachnid fly contributed to $22.58,9.68,3.23,6.45$ and 12.90 per cent parasitization, respectively, with total parasitization of 54.84 in second fortnight of October.

During 2016, total number of leaf folder larvae from 100 damaged leaves varied from 1.00 to 26.00 while number of parasitized larvae varied from 1.00 to 15.00 and the total parasitization varied from 27.27 to 66.67 per cent. The parasitization initiated in first fortnight of September and reached the peak of 66.67 per cent in first fortnight of October and per cent parsitization by $C$. cypris, C. ruficrus and tachnid fly was observed to be $44.45,11.11$ and 11.11 per cent, respectively (Table 7). 
Table.1 Details of localities surveyed for recording abundance of parasitoids associated with Cnaphalocrocis medinalis larvae in H.P

\begin{tabular}{|c|c|c|c|c|c|c|}
\hline $\begin{array}{c}\text { Agro- } \\
\text { ecological } \\
\text { Zone }\end{array}$ & Location & $\begin{array}{c}\text { Altitude } \\
\text { (m asl) }\end{array}$ & $\begin{array}{c}\text { Average } \\
\text { rainfall } \\
(\mathbf{m m})\end{array}$ & $\begin{array}{c}\text { Latitude } \\
{ }^{\circ} \mathbf{N}\end{array}$ & $\begin{array}{c}\text { Longitude } \\
{ }^{\circ} \mathbf{E}\end{array}$ & Localities \\
\hline $\begin{array}{c}\text { Zone I } \\
\text { Sub- } \\
\text { mountainous } \\
\text { and low hills } \\
\text { sub-tropical }\end{array}$ & Sundernagar & 656 & 1291 & 31.54 & 76.91 & $\begin{array}{c}\text { Jaral, Bharjwanu, Sai } \\
\text { and Dhanotu }\end{array}$ \\
\cline { 2 - 7 } & Nurpur & 643 & 1500 & 31.60 & 76.30 & $\begin{array}{c}\text { Rinna, Jonta, Rehan } \\
\text { and Bharmar }\end{array}$ \\
$\begin{array}{c}\text { Zone II } \\
\text { Mid hills sub- } \\
\text { humid }\end{array}$ & Jogindernagar & 1220 & 1851 & 31.98 & 76.77 & $\begin{array}{c}\text { Bir, Ahju, Sukhbagh } \\
\text { and Dhelu }\end{array}$ \\
\hline & Palampur & 1290 & 2300 & 32.10 & 76.52 & $\begin{array}{c}\text { Malan, Majhetli, } \\
\text { Pharer and Menjha }\end{array}$ \\
\hline
\end{tabular}

Table.2 Parasitization of Cnaphalocrocis medinalis larvae at Sundernagar during 2015

\begin{tabular}{|c|c|c|c|c|c|c|c|c|}
\hline \multirow{2}{*}{ Period } & \multirow{2}{*}{$\begin{array}{c}\text { Total } \\
\text { number of } \\
\text { larvae per } \\
100 \mathrm{DL}\end{array}$} & \multirow{2}{*}{$\begin{array}{c}\text { Total } \\
\text { parasitized } \\
\text { larvae }\end{array}$} & \multicolumn{5}{|c|}{ Parasitization (\%) } & \multirow{2}{*}{$\begin{array}{c}\text { Total } \\
\text { parasitization } \\
(\%)\end{array}$} \\
\hline & & & $\begin{array}{c}\text { C. } \\
\text { cypris }\end{array}$ & $\begin{array}{c}C . \\
\text { ruficrus }\end{array}$ & $\begin{array}{c}\text { Elasmus } \\
\text { sp. }\end{array}$ & $\begin{array}{c}T . \\
\text { flavoorbitalis }\end{array}$ & $\begin{array}{c}\text { Tachnid } \\
\text { Fly }\end{array}$ & \\
\hline July-I & 0.00 & 0.00 & 0.00 & 0.00 & 0.00 & 0.00 & 0.00 & 0.00 \\
\hline July-II & 2.00 & 0.00 & 0.00 & 0.00 & 0.00 & 0.00 & 0.00 & 0.00 \\
\hline Aug-I & 6.00 & 1.00 & 16.67 & 0.00 & 0.00 & 0.00 & 0.00 & 16.67 \\
\hline Aug-II & 9.00 & 2.00 & 11.11 & 11.11 & 0.00 & 0.00 & 0.00 & 22.22 \\
\hline Sept-I & 22.00 & 7.00 & 13.64 & 4.55 & 4.55 & 4.55 & 4.55 & 31.84 \\
\hline Sept-II & 16.00 & 10.00 & 31.25 & 6.25 & 6.25 & 6.25 & 12.50 & 62.50 \\
\hline Oct-I & 10.00 & 4.00 & 20.00 & 0.00 & 0.00 & 10.00 & 10.00 & 40.00 \\
\hline Oct-II & 7.00 & 1.00 & 14.29 & 0.00 & 0.00 & 0.00 & 0.00 & 14.29 \\
\hline Nov-I & 0.00 & 0.00 & 0.00 & 0.00 & 0.00 & 0.00 & 0.00 & 0.00 \\
\hline
\end{tabular}

DL: Damaged leaves $\quad$ I: First fortnight II: Second fortnight

Table.3 Parasitization of Cnaphalocrocis medinalis larvae at Sundernagar during 2016

\begin{tabular}{|c|c|c|c|c|c|c|c|c|}
\hline \multirow[t]{2}{*}{ Period } & \multirow{2}{*}{$\begin{array}{c}\text { Total } \\
\text { number of } \\
\text { larvae per } \\
100 \mathrm{DL}\end{array}$} & \multirow{2}{*}{$\begin{array}{c}\text { Total } \\
\text { parasitized } \\
\text { larvae }\end{array}$} & \multicolumn{5}{|c|}{ Parasitization (\%) } & \multirow{2}{*}{$\begin{array}{c}\text { Total } \\
\text { parasitization } \\
(\%)\end{array}$} \\
\hline & & & C. cypris & C. ruficrus & Elasmus sp. & T. flavoorbitalis & $\begin{array}{l}\text { Tachnid } \\
\text { Fly }\end{array}$ & \\
\hline June-II & 0.00 & 0.00 & 0.00 & 0.00 & 0.00 & 0.00 & 0.00 & 0.00 \\
\hline July-I & 1.00 & 0.00 & 0.00 & 0.00 & 0.00 & 0.00 & 0.00 & 0.00 \\
\hline Jul-II & 1.00 & 0.00 & 0.00 & 0.00 & 0.00 & 0.00 & 0.00 & 0.00 \\
\hline Aug-I & 2.00 & 0.00 & 0.00 & 0.00 & 0.00 & 0.00 & 0.00 & 0.00 \\
\hline Aug-II & 5.00 & 1.00 & 20.00 & 0.00 & 0.00 & 0.00 & 0.00 & 20.00 \\
\hline Sept-I & 18.00 & 5.00 & 11.11 & 0.00 & 5.55 & 5.55 & 5.55 & 27.76 \\
\hline Sept-II & 15.00 & 9.00 & 26.66 & 6.67 & 6.67 & 6.67 & 13.33 & 60.00 \\
\hline Oct-I & 4.00 & 1.00 & 25.00 & 0.00 & 0.00 & 0.00 & 0.00 & 25.00 \\
\hline Oct-II & 0.00 & 0.00 & 0.00 & 0.00 & 0.00 & 0.00 & 0.00 & 0.00 \\
\hline
\end{tabular}

DL: Damaged leaves $\quad$ I: First fortnight II: Second fortnight 
Table.4 Parasitization of Cnaphalocrocis medinalis larvae by Cotesia cypris at Nurpur during 2015 and 2016

\begin{tabular}{|c|c|c|c|c|c|c|}
\hline Period & \multicolumn{3}{|c|}{$\mathbf{2 0 1 5}$} & \multicolumn{3}{|c|}{$\mathbf{2 0 1 6}$} \\
\cline { 2 - 7 } & $\begin{array}{c}\text { Total } \\
\text { number of } \\
\text { larvae per } \\
\text { 100 DL }\end{array}$ & $\begin{array}{c}\text { Total } \\
\text { parasitized } \\
\text { larvae }\end{array}$ & $\begin{array}{c}\text { Parasitization } \\
(\boldsymbol{\%})\end{array}$ & $\begin{array}{c}\text { Total } \\
\text { number of } \\
\text { larvae per } \\
\mathbf{1 0 0} \text { DL }\end{array}$ & $\begin{array}{c}\text { Total } \\
\text { parasitized } \\
\text { larvae }\end{array}$ & $\begin{array}{c}\text { Parasitization } \\
(\%)\end{array}$ \\
\hline July-II & 0.00 & 0.00 & 0.00 & 0.00 & 0.00 & 0.00 \\
\hline Aug-I & 2.00 & 0.00 & 0.00 & 0.00 & 0.00 & 0.00 \\
\hline Aug-II & 3.00 & 0.00 & 0.00 & 2.00 & 0.00 & 0.00 \\
\hline Sept-I & 10.00 & 1.00 & 10.00 & 8.00 & 1.00 & 12.50 \\
\hline Sept-II & 17.00 & 2.00 & 11.76 & 12.00 & 1.00 & 8.33 \\
\hline Oct-I & 7.00 & 1.00 & 14.29 & 5.00 & 1.00 & 20.00 \\
\hline Oct-II & 3.00 & 0.00 & 0.00 & 0.00 & 0.00 & 0.00 \\
\hline Nov-I & 0.00 & 0.00 & 0.00 & 0.00 & 0.00 & 0.00 \\
\hline
\end{tabular}

DL: Damaged leaves

I: First fortnight II: Second fortnight

Table.5 Parasitization of Cnaphalocrocis medinalis larvae by C. cypris at Jogindernagar during 2015 and 2016

\begin{tabular}{|c|c|c|c|c|c|c|}
\hline Period & \multicolumn{3}{|c|}{$\mathbf{2 0 1 5}$} & \multicolumn{3}{|c|}{$\mathbf{2 0 1 6}$} \\
\cline { 2 - 7 } & $\begin{array}{c}\text { Total } \\
\text { number of } \\
\text { larvae per } \\
\mathbf{1 0 0 ~ D L}\end{array}$ & $\begin{array}{c}\text { Total } \\
\text { parasitized } \\
\text { larvae }\end{array}$ & $\begin{array}{c}\text { Parasitization } \\
(\mathbf{\%})\end{array}$ & $\begin{array}{c}\text { Total } \\
\text { number of } \\
\text { larvae per } \\
\mathbf{1 0 0} \text { DL }\end{array}$ & $\begin{array}{c}\text { Total } \\
\text { parasitized } \\
\text { larvae }\end{array}$ & $\begin{array}{c}\text { Parasitization } \\
(\mathbf{\%})\end{array}$ \\
\hline July-II & 0.00 & 0.00 & 0.00 & 0.00 & 0.00 & 0.00 \\
\hline Aug-I & 0.00 & 0.00 & 0.00 & 2.00 & 0.00 & 0.00 \\
\hline Aug-II & 4.00 & 0.00 & 0.00 & 8.00 & 1.00 & 12.50 \\
\hline Sept-I & 14.00 & 1.00 & 7.14 & 11.00 & 2.00 & 18.18 \\
\hline Sept-II & 22.00 & 3.00 & 13.64 & 19.00 & 4.00 & 21.05 \\
\hline Oct-I & 10.00 & 2.00 & 20.00 & 9.00 & 2.00 & 22.22 \\
\hline Oct-II & 2.00 & 0.00 & 0.00 & 0.00 & 0.00 & 0.00 \\
\hline Nov-I & 0.00 & 0.00 & 0.00 & 0.00 & 0.00 & 0.00 \\
\hline
\end{tabular}

DL: Damaged leaves

I: First fortnight II: Second fortnight 
Table.6 Parasitization of Cnaphalocrocis medinalis larvae at Palampur during 2015

\begin{tabular}{|c|c|c|c|c|c|c|c|c|}
\hline \multirow[t]{2}{*}{ Period } & \multirow{2}{*}{$\begin{array}{c}\text { Total } \\
\text { number of } \\
\text { larvae per } \\
100 \mathrm{DL}\end{array}$} & \multirow{2}{*}{\begin{tabular}{|c} 
Total \\
parasitized \\
larvae
\end{tabular}} & \multicolumn{5}{|c|}{ Parasitization (\%) } & \multirow{2}{*}{$\begin{array}{c}\text { Total } \\
\text { parasitization } \\
(\%)\end{array}$} \\
\hline & & & $\begin{array}{c}\text { Cy } \\
\text { cypris }\end{array}$ & $\begin{array}{c}C . \\
\text { ruficrus }\end{array}$ & $\begin{array}{c}\text { Elasmus } \\
\text { sp. }\end{array}$ & $\begin{array}{c}T . \\
\text { flavoorbitalis }\end{array}$ & $\begin{array}{l}\text { Tachnid } \\
\text { Fly }\end{array}$ & \\
\hline Aug-I & 0.00 & 0.00 & 0.00 & 0.00 & 0.00 & 0.00 & 0.00 & 0.00 \\
\hline Aug- & 7.00 & 1.00 & 14.29 & 0.00 & 0.00 & 0.00 & 0.00 & 14.29 \\
\hline Sep-I & 11.00 & 4.00 & 9.09 & 9.09 & 0.00 & 9.09 & 9.09 & 36.36 \\
\hline Sep-II & 31.00 & 17.00 & 22.58 & 9.68 & 3.23 & 6.45 & 12.90 & 54.84 \\
\hline Oct-I & 14.00 & 9.00 & 42.87 & 0.00 & 0.00 & 7.14 & 14.28 & 64.29 \\
\hline Oct-II & 6.00 & 3.00 & 33.33 & 0.00 & 16.67 & 0.00 & 0.00 & 50.00 \\
\hline Nov-I & 5.00 & 1.00 & 20.00 & 0.00 & 0.00 & 0.00 & 0.00 & 20.00 \\
\hline
\end{tabular}

DL: Damaged leaves I: First fortnight II: Second fortnight

Table.7 Parasitization of Cnaphalocrocis medinalis larvae at Palampur during 2016

\begin{tabular}{|c|c|c|c|c|c|c|c|c|}
\hline \multirow[t]{2}{*}{ Period } & \multirow{2}{*}{$\begin{array}{c}\text { Total } \\
\text { number of } \\
\text { larvae per } \\
100 \mathrm{DL}\end{array}$} & \multirow{2}{*}{$\begin{array}{c}\text { Total } \\
\text { parasitized } \\
\text { larvae }\end{array}$} & \multicolumn{5}{|c|}{ Parasitization (\%) } & \multirow{2}{*}{$\begin{array}{c}\text { Total } \\
\text { parasitization } \\
(\%)\end{array}$} \\
\hline & & & $\begin{array}{c}C . \\
\text { cypris }\end{array}$ & $\begin{array}{c}\text { C. } \\
\text { ruficrus }\end{array}$ & $\begin{array}{c}\text { Elasmus } \\
\text { sp. }\end{array}$ & $\begin{array}{c}T . \\
\text { flavoorbitalis }\end{array}$ & $\begin{array}{c}\text { Tachnid } \\
\text { Fly }\end{array}$ & \\
\hline Jul-II & 0.00 & 0.00 & 0.00 & 0.00 & 0.00 & 0.00 & 0.00 & 0.00 \\
\hline Aug-I & 1.00 & 0.00 & 0.00 & 0.00 & 0.00 & 0.00 & 0.00 & 0.00 \\
\hline Aug- & 1.00 & 0.00 & 0.00 & 0.00 & 0.00 & 0.00 & 0.00 & 0.00 \\
\hline Sep-I & 11.00 & 3.00 & 9.09 & 0.00 & 9.09 & 9.09 & 0.00 & 27.27 \\
\hline Sep-II & 26.00 & 15.00 & 26.92 & 7.69 & 3.85 & 3.85 & 15.38 & 57.69 \\
\hline Oct-I & 9.00 & 6.00 & 44.45 & 11.11 & 0.00 & 0.00 & 11.11 & 66.67 \\
\hline Oct-II & 3.00 & 1.00 & 33.33 & 0.00 & 0.00 & 0.00 & 0.00 & 33.33 \\
\hline Nov-I & 0.00 & 0.00 & 0.00 & 0.00 & 0.00 & 0.00 & 0.00 & 0.00 \\
\hline
\end{tabular}


Fig.1 Parasitoids associated with Cnaphalocrocis medinalis (a) Larvae of Elasmus sp. (b) Adult Elasmus sp. (c) Larva of Cotesia cypris (d) Cocoon of C. cypris (e) Adult C. cypris (f) Pupa of Trathala flavoorbitalis (g) Adult T. flavoorbitalis (h) Adult C. ruficrus (i) Pupa of Tachnif fly (j) Adult Tachnid fly

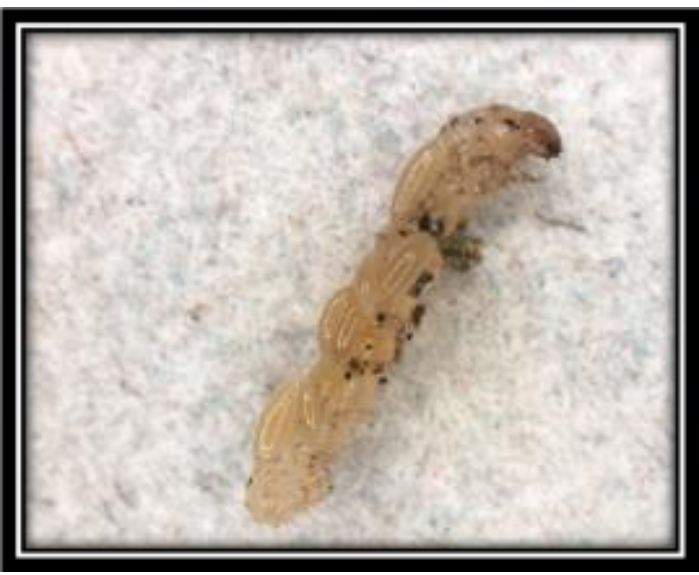

(a)

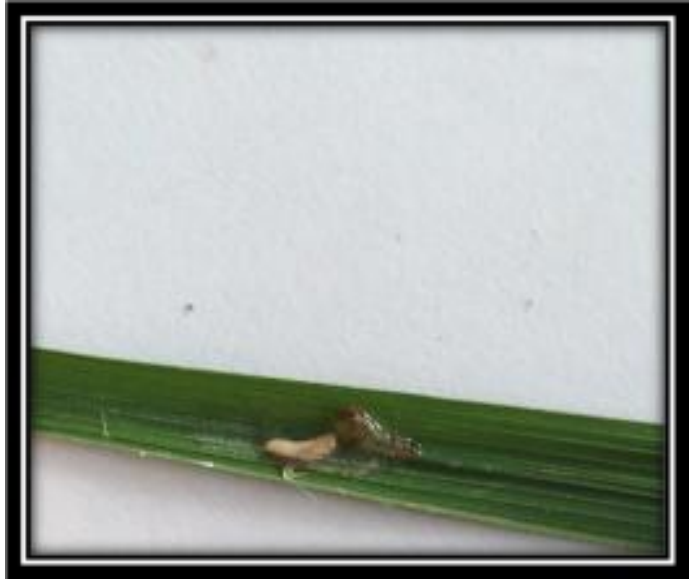

(c)

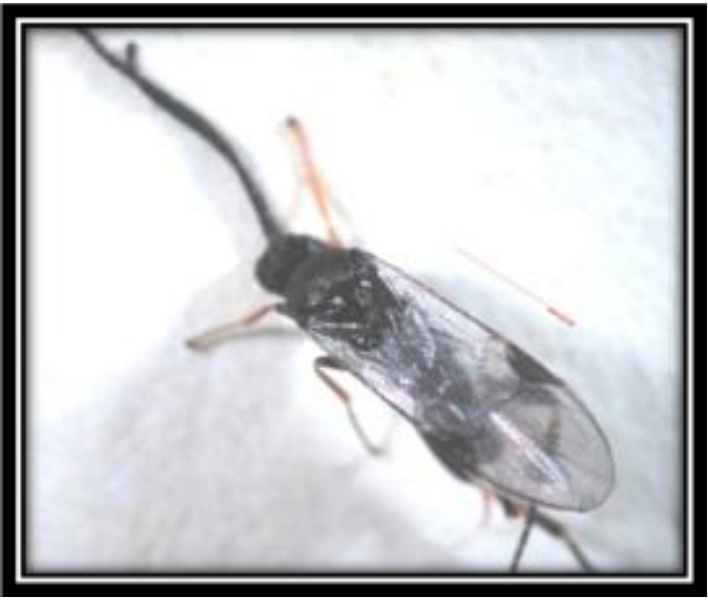

(e)

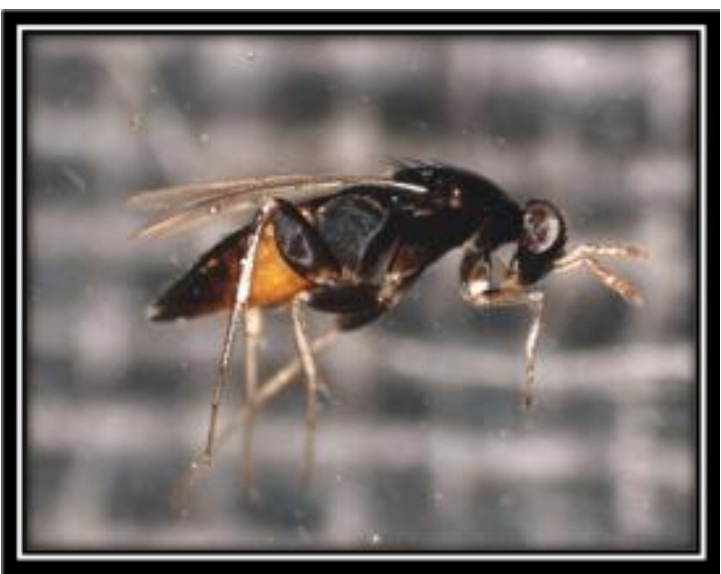

(b)

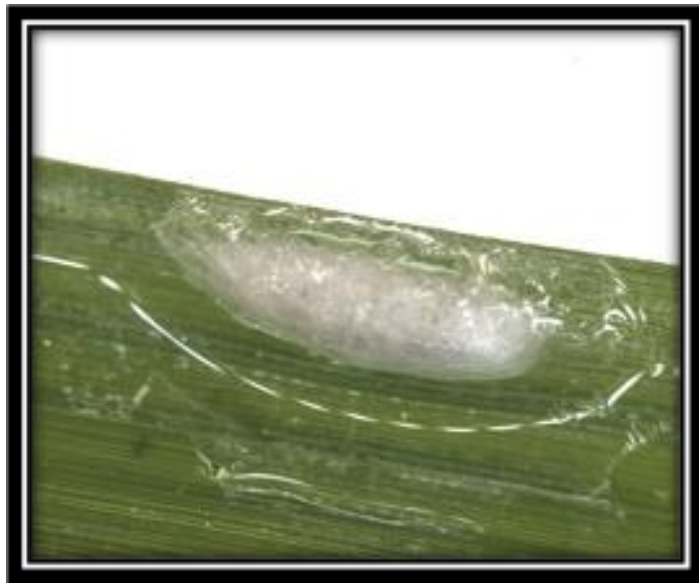

(d)

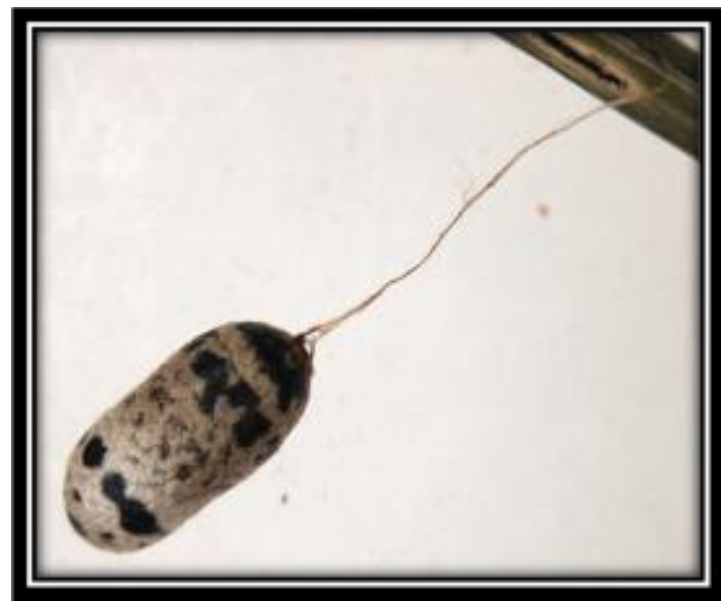

(f) 


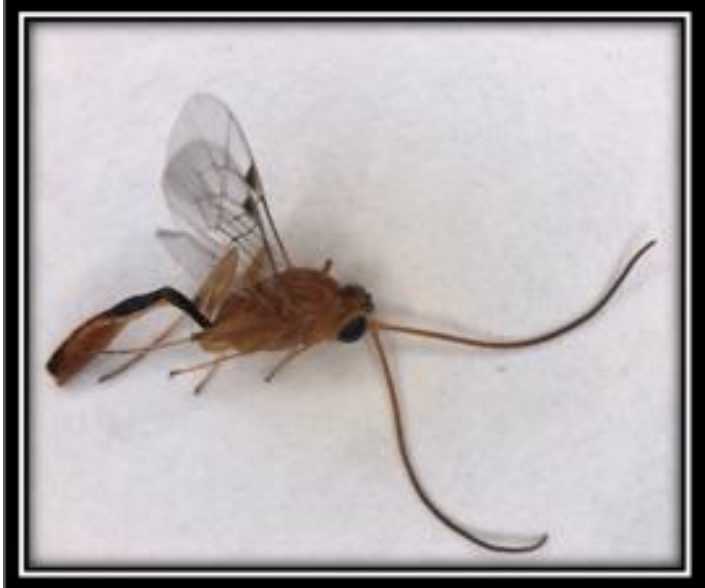

(g)

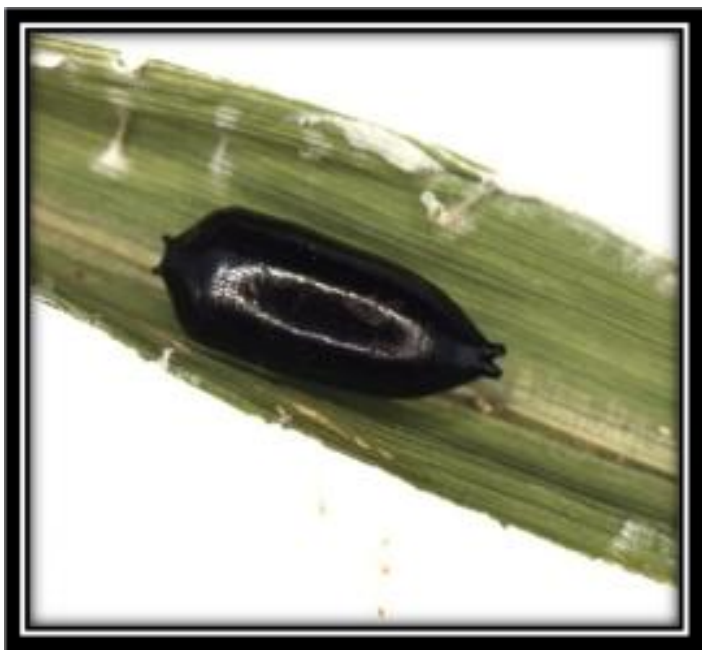

(i)

Different workers also recorded C. cypris as one of the most dominating larval parasitoid of the rice leaf folder from different parts of country (Natarajam et al., 1980; Mishra \& Mandal 2003; Rani et al., 2007). The seasonal percentage of larval parasitism ranged from 14 to 56 per cent (Kraker et al., 1999). However, the present investigation draws support from their results wherein parasitization by $C$. cypris ranged from 7.14 to 44.45 per cent.

All the five parasitoids namely, $C$. cypris, $C$. ruficrus, Elasmus sp., T. flavoorbitalis and tachnid fly recorded in present studies have been reported as important parasitoids of rice

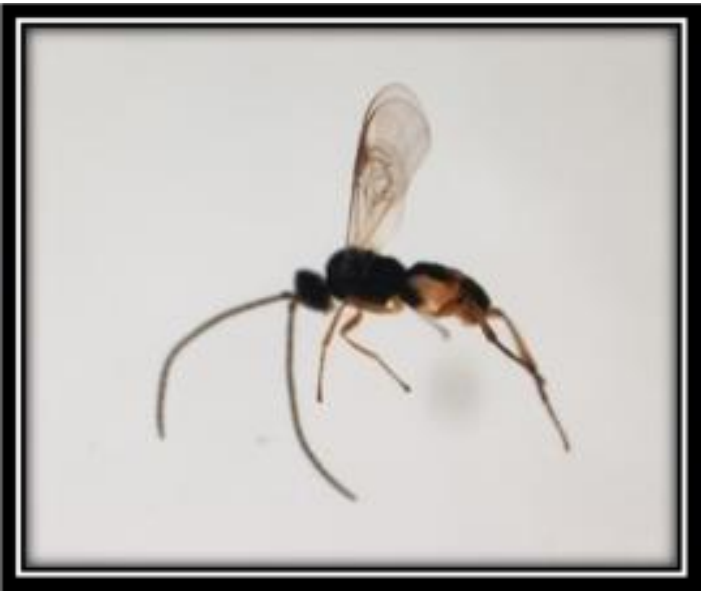

(h)

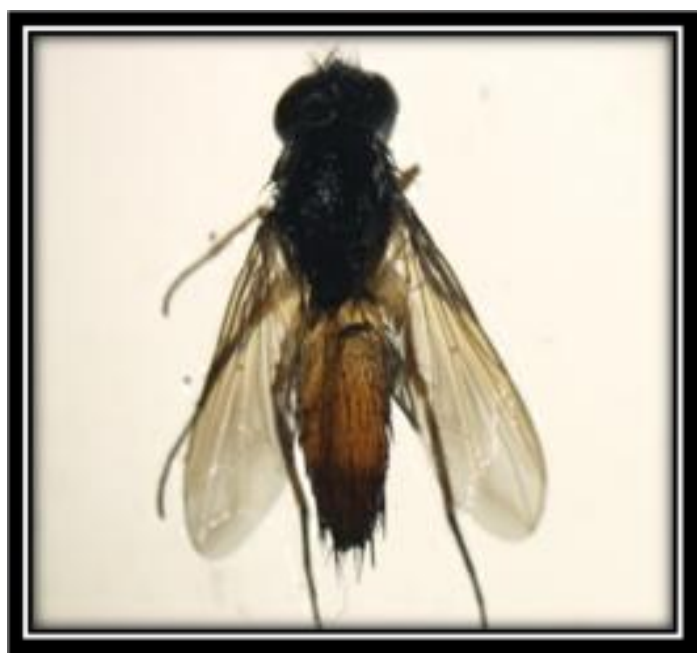

(j)

leaf folder by various workers (Arida and Shepard 1990; Rani et al., 2007; Dhanapatidevi \& Varatharajan 2013; Pathak et al., 2011).

Five parasitoids namely, Cotesia cypris Nixon, C. ruficrus Haliday, Trathala flavoorbitalis Cameron, Elasmus sp., and tachnid fly were specific to $C$. medinalis larvae and these need to be conserved by use of selective pesticides. Cotesia cypris was dominant in all the locations resulting in higher parasitization of $C$. medinalis larvae compared to all other parasitoids. As it is evident that biological control is an important 
component of IPM so the potential of $C$. cypris can be harnessed for the management of this pest.

\section{Acknowledgement}

The authors are thankful to Department of Entomology CSK Himachal Pradesh Krishi Vishvavidyalaya, Palampur-176062, India for providing all facilities required during experimental work. Authors are also thankful to Dr. P.M. Sureshan, Western Ghat Regional Centre, Zoological Survey of India, Kerala (Hymenoptera) and Dr. Ankita Gupta, ICARNational Bureau of Agricultural Insect Resources, Bangalore (Hymenoptera) for identification of parasitoid samples and sharing with us the valuable aspects pertaining to research work.

\section{References}

Arida, G. S. and Shepard, B. M., 1990, Parasitism and predation of rice leaf folders, Marasmia patnalis (Bradley) and Cnaphalocrocis medinalis (Guenee) (Lepidoptera: Pyralidae) in Laguna province, Philippines. Journal of Agricultural Entomology, 7 (2): 113-118.

Basit, A. and Bhattacharya, B., 2001, Status of biological control in rice insect pest management. In: Biocontrol potential and its exploitation in sustainable agriculture. Vol. 2. Upadhyay, R.K., Mukhkerji, K.G. and Chambola, B.P. (eds). Kluwer-Academic/ Plenum Publishers, New York, 113p.

Bhattacharya, B., Basit, A. and Saikia., 2006, Parasitoids and predators of rice insect pests of Jorhat districts of Assam. Journal of Biological Control, 20 (1): 37-44.

Dhanapatidevi, K. and Varatharajan, R., 2013, Parasitoids of the rice insect pests from
Manipur. Indian Journal of Entomology, 75 (4): 269-273.

Karthick, K. S., Kandibane, M. and Kumar, K., 2014, Safety of newer insecticides to natural enemies in the coastal rice ecosystem of Karaikal, U.T. of Puducherry. Journal of Biopesticides, 7 (2): 195-198.

Khan, Z. R., Barrion, A. T., Litsinger, J. A., Castilla, N. P. and Joshi, R. C., 1988, Mini Review: A bibliography of rice leaf folders (Lepidoptera: Pyralidae). Insect Science and its application, 9: 129-174.

Korat, D. M. and Pathak, A. R., 1996, Present status of rice leaf folder, Cnaphalocrocis medinalis Guen. and its management in Gujarat. Pestology, 20 (7): 5-10.

Kraker, J. D., Huis, A. V., Heong, K. L., Lenteren, J. C. V. and Rabbinge, R., 1999, Population dynamics of rice leaf folder (Lepidoptera: Pyralidae) and their natural enemies in irrigated rice in the Philippines. Bulletin of Entomology Research, 89 (5): 411421.

Kumar, S., Kaul, B. K. and Kumar, S., 1997, Natural enemies of rice stem borers in Kangra valley of Himachal Pradesh. Journal of Biological control, 11 (1-2): 69-71.

Litsinger, J. A., Canapi, B. L., Bandong, J. P. and Cruz, C. G. D., 1987, Rice crop loss from insect pests in wetland and dryland environments of Asia with emphasis on the Philippines. Insect Science and its Application, 8 (4-6): 677-692.

Mishra, B. K. and Mandal, S. M. A., 2003, Density dependant parasitization of rice leaf folder, Cnaphalocrocis medinalis (Guenee) in the coastal belt of Orissa. Journal of Applied zoological Research, 14 (1): 63-64. 
Natarajam, K., Rajamani, S. and Mathur, K. C., 1980, Brachmia arotrae, a leaf folder of rice in India. International Rice Research Newsletter, 3 (3): 16.

Panda, B. M. and Rath, L. K., 2003, Efficacy of certain newer formulations of insecticides for the control of Sogatella furcifera (Horvath) in rice. Indian Journal of Plant Protection, 31 (2): 28-30.

Pathak, M., Rizvi, P. Q., Kumar, P., Garg, D. K. and Singh, N. K., 2011, Natural enemies of rice insect pests in ricewheat cropping system of Northern
Indo-gangetic plains. Oryza, 48 (4): 383-386.

Rani, W. B., Amutha, R., Muthulakshmi, S., Indira, K. and Mareeswari, P., 2007, Diversity of rice leaf folders and their natural enemies. Research Journal of Agriculture and Biological Sciences, 3 (5): 394-397.

Shanmugam, T. R., Sendhil, R. and Thirumalvalavan, V. V., 2006, Quantification and prioritization of constraints causing yield loss in rice (Oryza sativa) in India. Agricultura Tropica et Subtropica, 39 (3): 194201.

\section{How to cite this article:}

Chhavi, Pawan K. Sharma and Sharma, P. C. 2019. Survey Studies on Seasonal Abundance of Parasitoids associated with Cnaphalocrocis medinalis Guenee in Zone I and Zone II of Himachal Pradesh, India. Int.J.Curr.Microbiol.App.Sci. 8(12): 2444-2753.

doi: https://doi.org/10.20546/ijcmas.2019.812.321 